\title{
Protective effects of quality certified traditional Doenjang in Korea on TNF- $a$-induced vascular inflammation in human umbilical vein endothelial cells
}

\author{
Eun-Ju Kim, Yeon-Jeong Jang, So-Young Kim, Hye-Sun Choi, Shin-Young Park* \\ Fermentated Food Science Division, National Institute of Agricultural Sciences, RDA, Wanju 55365, Korea
}

\section{혈관내피세포에서 TNF- $a$ 자극에 의해 유도되는 혈관염증에 대한 전통식품 품질인증 된장의 효능 평가}

\author{
김은주 · 장연정 · 김소영 · 최혜선 · 박신영* \\ 농촌진흥청 국립농업과학원 농식품자원부 발효식품과
}

\begin{abstract}
Anti-atherogenic effects in tumor necrosis factor- $a$ (TNF- $a$ )-stimulated human umbilical vein endothelial cells (HUVEC) are involved in the suppression of oxidative stress, cell adhesion molecules, and pro-inflammatory factors. This study investigated the vascular inflammation inhibitory activity of traditional Doenjang plays a key role in the pathogenesis and progression of atherosclerosis. The protective effects of Korean Deonjang was investigated on the expression of cell adhesion molecules (CAMs) in tumor necrosis factor (TNF)- $a$-induced human umbilical vascular endothelial cells (HUVECs). Deonjang extracts $(20,50,100 \mu \mathrm{g} / \mathrm{mL}$ ) decreased the expression of $20 \mathrm{ng} / \mathrm{mL}$ TNF- $a$-induced vascular cell adhesion molecule (VCAM)-1 intracellular adhesion molecule (ICAM)-1 proteins, and their corresponding mRNA levels. Nitric oxides (NO) produced by endothlial nitric oxides synthase (eNOS) dilated blood vessels, which had protective effects against platelet and leukocyte adhesion. While TNF-a-induced suppressed the production of nitric oxide in HUVECs, Doenjang restored NO production in HUVECs. In addition, Deonjang reduced the TNF-a-induced expression of inducible NO synthase (iNOS) and cyclooxygenase (COX)-2 mRNA levels. These results suggested that Doenjang can inhibited the production of cell adhesion molecules and inflammatory mediators, which could be a potential candidate for preventing atherosclerosis.
\end{abstract}

Key words : Doenjang, HUVECs, tumor necrosis factor (TNF)-a, inflammation

\section{서 론}

우리나라의 대표적인 전통 발효 식품중의 하나인 된장은 대두를 찐 다음 으깨어 만든 메주에서 발효균이 콩의 고분 자 영양소를 발효 분해하여 맛과 소화력 및 저장성을 증진 시킨 식품이다(1). 된장은 아미노산 조성이 우수한 단백질 과 불포화지방산 형태로 구성된 지방, 탄수화물과 같은 주

*Corresponding author. E-mail : soyoenj@korea.kr Phone : 82-63-238-3625, Fax : 82-63-238-3843

Received 19 April 2016; Revised 3 June 2016; Accepted 13 June 2016.

Copyright (c) The Korean Society of Food Preservation. All rights reserved.
요 영양분뿐만 아니라 무기물을 함유하며 또한 된장이 되기 까지 대두는 장기간 숙성 과정을 거치므로 대두가 가지고 있는 여러 활성 물질들 이외에도 발효과정 동안 원재료인 대두에서는 존재하지 않거나 함량이 적은 활성성분들이 생성되거나 증가되는 것으로 알려져 있다(2). 된장의 발효 는 콩의 유용한 성분을 인체에 흡수가 잘 되는 물질로 변화 시키는 것으로 알려져 있다(3). 콩의 여러 가지 이로운 성분 중 하나는 isoflavone이며 콩의 isoflavone은 glucoside 형태 인 genistin, daidzin, glycitin 등으로 형성되어 있다. 하지만 된장에서 콩의 발효가 진행됨에 따라 이들은 각각 aglycon 형태인 genistein, daidzein, glycitein으로 전환된다(4). 이러 한 aglycon된 형태의 genistein, daidzein은 항염증(5), 항산화 (6), 항암효과(7)를 가진 것으로 알려져 있으며 된장이 발효 
되면서 이러한 성분이 많이 생성된다(4). 최근 전통된장에 관한 연구로는 항 돌연변이(8), 항암(8-10) 및 면역증진(11) 이나 혈압강하(12,13), 고지혈증과 당뇨개선(14), 항산화능 (15-17)등의 생체조절 기능 식품성분들이 일부 밝혀지고 있다.

혈관내피세포는 백혈구 부착 방지 및 혈소판의 응집과 부착 방지, 동맥 혈관 평활근 증식억제 등과 같은 기전을 통하여 혈관 항상성 유지에 중요한 역할을 한다(18). 염증반 응에 관여하는 주요 세포는 macrophage로 알려져 있으며, 여러 자극이나 면역세포들이 분비하는 사이토카인 등에 의해 활성화되어, pro-inflammatory cytokine, nitric oxide (NO)와 prostaglandin E2(PGE2)를 생성함으로써 통증, 부 종, 열 등의 염증반응을 유발하고, 염증부위로 면역세포의 이동을 촉진시킨다(19). 염증반응의 지표물질인 NO는 L-arginine에서 NO synthase(NOS)에 의해 합성된다. NOS 에는 endothelial NOS(eNOS), neuronal NOS(nNOS), inducible NOS(iNOS)의 세 가지 형태가 있으며, 이들 중 $\mathrm{iNOS}$ 는 외부자극이나 pro-inflammatory cytokine 등에 의해 자극 받게 되면 hepatocytes, smooth muscle cells, bone marrow cells, monocytes, macrophages 등 다양한 세포에서 발현되어 다량의 $\mathrm{NO}$ 를 생산한다고 보고되고 있다 $(20,21)$. 혈관내의 염증은 활성화된 백혈구가 ROS를 생성하여 염증 반응 전사인자인 nuclear factor(NF)- $\kappa \mathrm{B}$ 를 활성화시키고, 그 결과 intercellular adhesion molecule(ICAM)-1, vascular cell adhesion molecule(VCAM)-1과 monocyte chemoattractant protein-1(MCP-1)등 세포부착인자들을 발현함으로서 혈관 내벽으로 monocyte 유입을 유도하여 동맥경화를 진행시킨 다 $(22,23)$. 그러므로 동맥경화는 산화적 스트레스에 의해 활성화된 대식세포가 중요한 역할을 담당하는 만성적 염증 질환이라 할 수 있다 $(24,25)$. 많은 연구자들은 성인병 예방 을 위한 연구의 일환으로 식품이 함유하고 있는 많은 기능 성 물질들을 활용하고 있다. 지금까지 진행된 된장 관련 연구는 기능성 소재를 첨가하여 된장을 제조하거나 특정 미생물을 사용하여 제조한 된장에 관한 연구로 시판되고 있는 제품에서의 기능성에 관한 연구는 아직 미비한 실정이 다. 전통식품의 발전과 세계화를 위해서는 우수한 전통식 품의 품질을 보증하고, 음식의 맛과 질을 표준화하는 기본 장치인 국가 인증제도가 필요함에 따라(26), 2012년 기준 된장품목에서는 51 개 제품이 전통식품 품질인증을 받아 생산 및 판매되고 있다(27). 이에 본 연구에서는 국내산 농수산물을 주재료로 하여 제조, 가공, 조리되어 우리 고유 의 맛, 향, 색을 내는 우수한 전통식품에 대하여 정부가 품질을 보증하는 '전통식품 품질인증'을 받은 24 개 장류 업체 및 시판 생산되는 장류제품을 대상으로 진행한 전통식 품 품질인증 된장의 품질특성 선행연구(28)를 통해 품질우 수성과 안전성이 확보된 전통된장 중 전통기법을 사용하 고, 1 년 이상 장기간 숙성된장 2 종을 선발하여 혈관염증질
환 소재로서의 가능성을 확인하고자 하였다.

\section{재료 및 방법}

\section{추출물 제조}

전통식품 품질인증 된장시료 중 1 년 이상 장기간 숙성 Deonjang(DJ\#3, DJ\#13) 시료 $10 \mathrm{~g}$ 에 증류수 $100 \mathrm{~mL}$ 을 가하 여 $80^{\circ} \mathrm{C}$ 에서 24 시간 동안 $150 \mathrm{rpm}$ 으로 교반시켜 3회 추출하 였으며 $4^{\circ} \mathrm{C}$ 에서 $800 \mathrm{rpm}$ 으로 5 분간 원심분리 하였다. 분리 된 상등액을 Whatman No.1 filter paper로 여과한 후 여액을 수거하여 동결건조 시킨 뒤 시료로 사용하였다.

\section{혈관내피세포의 배양}

인간 혈관내피세포(Human umbilical vascular vein endothelial cells, HUVECs)는 American Type Culture Collection(ATCC, Manassas, VA, USA)에서 분양하여 사용 하였다. 혈관내피세포는 $10 \%$ fetal bovine serum(FBS), $1 \%$ antibiotic-antimycotic(GIBCO, Invitrogen, Carlsbad, CA, USA), $0.1 \mathrm{mg} / \mathrm{mL}$ heparin(Sigma, St. Louis, MO, USA), 0.03 $\mathrm{mg} / \mathrm{mL}$ endothelial cell growth supplement(ECGS, ATCC, Manassas, VA, USA) 함유한 F-12K 배지에서 $5 \% \mathrm{CO}_{2}$ 배양 기로 $37^{\circ} \mathrm{C}$ 조건에서 배양하였다. 배양액은 3 4일 간격으로 갈아주었으며, 세포 배양접시에 cell density가 80 90\% 정도 자라게 되면 $0.25 \%$ trypsin-EDTA(0.53 mM EDTA)(Gibco, USA)를 처리하여 계대배양 하였다.

\section{세포 생존율 측정}

세포의 생존율은 3-(4,5-dimethylthiazole-2-y1)-2,5diphenyldiphenyl- tetrazolium bromide(MTT) 환원 방법을 이용하여 측정하였다(29). 혈관내피세포를 $1 \times 10^{6}$ cells/well 로 96-well plates에 분주한 후 48시간 배양한 다음, DJ\#3과 $\mathrm{DJ \# 13}$ 추출물을 $10,20,50,100 \mu \mathrm{g} / \mathrm{mL}$ 을 처리한 후 24시간 동안 $5 \% \mathrm{CO}_{2}$ 배양기 내에서 배양하여 $\mathrm{MTT}$ 를 환원시켜 생 성된 formazan crystal이 배지에 떨어져나 가지 않도록 배지 를 조심스럽게 제거하였다. dimethyl sulfoxide(DMSO, Sigma, St. Louis, MO, USA)를 $200 \mu \mathrm{L}$ 분주하여 20분 동안 혼합한 후 $570 \mathrm{~nm}$ 에서 흡광도를 측정하였다. 세포생존율은 대조군에 대한 백분율로 나타내었다.

\section{Nitric oxide(NO) 함량 측정}

혈 관내피세포를 $1 \times 10^{6}$ cells/well로 24-well plate에 분주 하여 48 시간 배양한 다음, DJ\#3과 DJ\#13 추출물을 10,20 , $50,100 \mu \mathrm{g} / \mathrm{mL}$ 을 농도로 처리하여 4시간 배양한 후, tumer necrosis factor(TNF)- $\alpha(20 \mathrm{ng} / \mathrm{mL})$ 를 각각 주입한 다음 혈관 내피세포를 18 시간 배양하였다. $100 \mathrm{uL}$ 의 배지 상층액에 Griess reagent(1\% sulfanilamide, $0.1 \%$ N-(1-naphthyl)- 
ethylene diamine dihydrochloride in $2.5 \%$ phosphoric acid solution)를 $50 \mu \mathrm{L}$ 주입한 후 10 분간 상온에서 방치한 후 $540 \mathrm{~nm}$ 에서 흡광도를 측정하였다. 이때 표준곡선은 $\mathrm{NaNO}_{2}$ 를 농도별로 조제하여 사용하였다(30).

ELISA 측정 (Enzyme-Linked Immunosorbent Assay) 세포 배양액 내의 CAMs(VCAM-1, ICAM-1)양을 측정하 기 위해 ELISA를 수행하였다. 혈관내피세포를 $1 \times 10^{6}$ cells/well로 24-well plate에 분주한 세로를 48시간 후에 $\mathrm{DJ} \# 3$ 과 DJ\#13 추출물을 농도별로 처리하고 4시간 후 20 $\mathrm{ng} / \mathrm{ml}$ 의 TNF- $a$ 를 처리하였다. 18 시간 후 세포 배양 액을 CAMs(VCAM-1, ICAM-1 Human ELISA kit)(abcam, UK.) 측정에 이용하였다. 배양액을 적절한 농도로 희석한 후, CAMs로 coating된 96-well plate 에 $50 \mu \mathrm{L}$ 씩 첨가하여 상온 에 2시간 반응시켰다. Washing buffer로 3 회 세척하고 100 $\mu \mathrm{L}$ 의 biotinylated antibody reagent를 각각의 well에 처리하 여 1 시간 동안 상온에서 반응시킨 후 3 회 세척한 다음, 100 $\mu \mathrm{L}$ 의 streptavidine-HRP solution을 처리하여 1 시간 동안 상 온에서 반응시킨 후 다시 washing buffer로 3 회 세척하였다. 여기에 di(2-ethylhexyl)-2,4,5-trimethoxy benzalmalonate(TMB) substrate를 $100 \mu \mathrm{L}$ 씩 처리하여 5 30분간 반응시킨 후 100 $\mu \mathrm{L}$ 의 stop solution을 처리한 후 $450 \mathrm{~nm}$ 에서 흡광도를 측정 하였다.

\section{RT-PCR}

Total RNA의 추출은 RNeasy Mini Kit(Qiagen, Valencia, $\mathrm{CA}, \mathrm{USA}$ )를 사용하여 수행하였고, total RNA에서 $\mathrm{cDNA}$ 를 합성은 oligo dT primer와 amfiRivert cDNA Synthesis Platinum Master Mix(GenDEPOT, USA)를 사용하였다. 이 cDNA를 template로 사용하여 VCAM-1, ICAM-1, eNOS, iNOS and COX-2의 유전자를 reverse transcription-polymerase chain reaction(RT-PCR) 방법으로 증폭하였다. 이때 housekeeping 유전자인 glyceraldehyde-3-phosphate dehydrogenase $(\mathrm{GAPDH})$ 유전자를 포함하여 internal control로 사용하였 다. 각 $\mathrm{PCR}$ 산물들을 $1 \%$ agarose gel을 이용하여 전기영동 하고 safe-pinky DNA Gel staining solution을 이용하여 염색 한 후 UV 하에서 확인하였다. 측정하고자 하는 mRNA는 $\mathrm{GAPDH}$ 로 수치를 정량화 하였고 Image Lab statistical software(Bio-Rad, CA, USA)을 사용하여 계산하였다. 각각 mRNA primer는 Cosmo Genetech(Seoul, Korea)에서 제작하 였으며 다음과 같다.

GAPDH, sense 5'-CAAGGTCATCCATGACAACTTT G-3' anti-sense 5'-GTCCACCACCCTGTTGCTGTAG-3'; COX-2, sense 5'-CTTGGGTGTCAAAGGTAA-3' anti-sense 5'-AGGGACTTGAGGAGGGTA-3'; iNOS, sense 5'-TCTTGG TCAAAGCTGTGCTC-3' anti-sense 5'-CATTGCCAAACG TACTGGTC-3'; eNOS, sense 5'-GTGTTTGGCCGAGTCC
TCACC-3' anti-sense5'-CTCCTGCAAGGAAAAGCTCTG-3'; VCAM-1, sense 5'-AAGATGGTCGTGATCCTTGG-3', anti-sense 5'-GGTGCTGCAAGTCAATGAGA-3'; ICAM-1, sense 5'-GGCTGGAGCTGTTTGAGAAC-3', anti-sense 5'-CTGACAAGTTGTGGGGGAGT-3'.

Western blot

혈관내피세포를 $100 \mathrm{~mm}$ dish에 $3 \times 10^{5}$ cells/well농도로 24 시간 배양한 후 DJ\#3 추출물을 농도별로 처리하고, 4 시간 후 $20 \mathrm{ng} / \mathrm{mL}$ 의 TNF- $a$ 를 첨가하였다. 18시간 배양 후 DPBS 로 3회 세척한 후 세포를 얻어 원심 분리하여 pellet에 RIPA buffer를 첨가한 다음, $4^{\circ} \mathrm{C}, 13,000 \times \mathrm{g}$ 에서 10 분간 원심 분리 하고 상등액을 튜브에 옮겼다. 단백질 정량은 Bradford (Bio-Rad, USA)를 이용하였고 각각의 시료를 $12 \% \mathrm{SDS}$ polyacrylamide gel에서 영동하고 Nitrocellulose membrane (NC membrane)으로 전사하였다(31). 전사된 $\mathrm{NC}$ membrane 을 5\% 무지방유가 포함된 신선한 blocking buffer( $0.1 \%$ Tween 20 in Tris-buggered saline) 에서 blocking한 후 1차 antibody(ICAM-1, VCAM-1, pp38, p-ERK, $\beta$-actin)를 1:200 1:1000으로 희석하여 넣고 1 시간 동안 반응시켰다. 다시 2차 antibody(Anti-mouse $\mathrm{IgG}$, Anti-rabbit $\mathrm{IgG}$ )를 $1: 1000$ 으로 희석하여 넣고 1 시간 동안 반응한 다음, $\mathrm{ECL}$ solution을 반응시켜 단백질 발현 정도를 Chemidoc image analyzer(Bio-Rad, Hercules, CA, USA)를 사용하여 측정 후 정 량하였다.

\section{통계처리}

본 실험의 결과는 3회 반복 실험을 실시한 뒤 mean \pm $\mathrm{SEM}$ 으로 나타내었으며, 각 군 간의 유의성의 검증은 SPSS 17.0 version(SPSS Inc., Chicago, IL, USA)을 이용하여 Student t-test및 ANOVA 법으로 검증하여 p값이 0.05 미만 을 유의한 것으로 간주하였다.

\section{결과 및 고찰}

혈관내피세포에 DJ\#3과 DJ\#13 추출물에 의한 세포 독성 평가

MTT assay를 이용하여 혈관내피 세포에서 DJ\#3과 $\mathrm{DJ \# 13}$ 추출물의 세포독성을 확인하였다. 그 결과 control군 과 비교해 DJ\#3과 DJ\#13 추출물을 농도별 $(10,20,50,100$ $\mu \mathrm{g} / \mathrm{mL}$ )로 처리한 군 모두 $90 \%$ 이상 생존율을 보여 혈관내 피세포에서 독성을 나타내지 않는 것을 확인하였다(Fig. 1). 본 실험에서는 DJ\#3과 DJ\#13 추출물의 농도가 세포독성 에 영향을 미치지 않는다고 사료되어, DJ\#3과 DJ\#13 추출 물 $20,50,100 \mu \mathrm{g} / \mathrm{mL}$ 의 농도로 추출물을 실험에 이용하였다. 

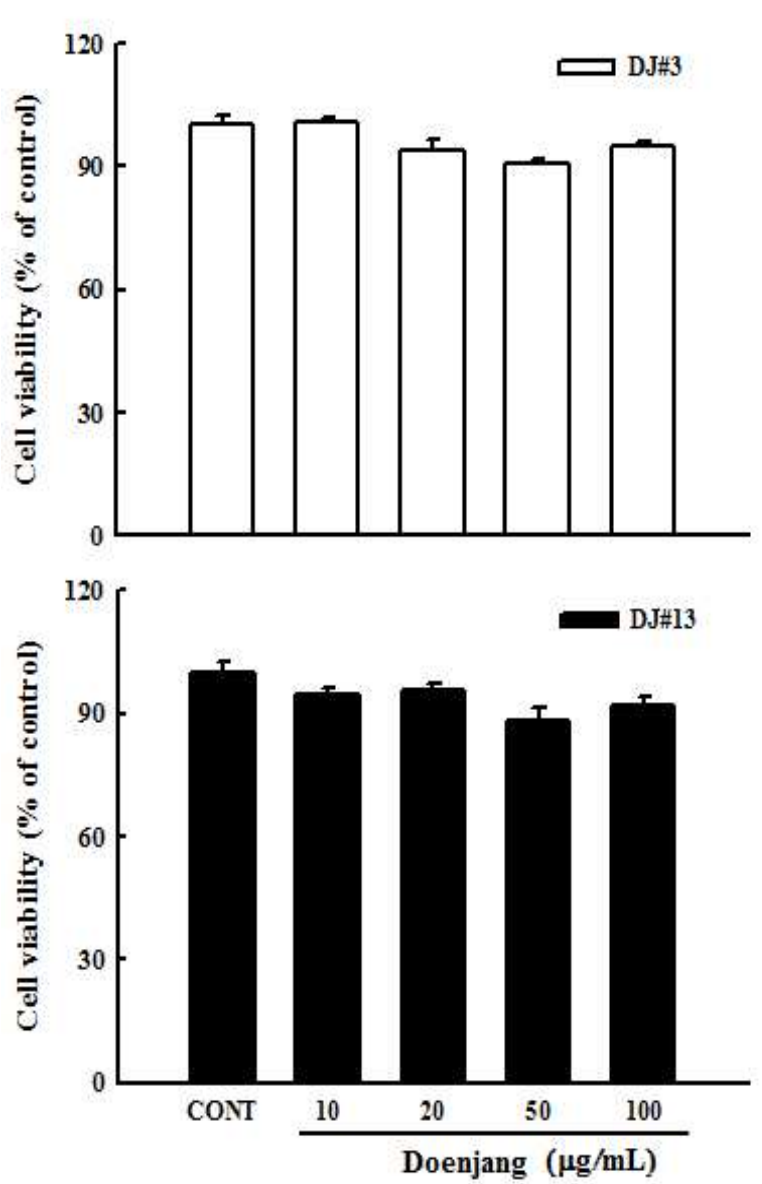

Fig. 1. Effect of doenjang extracts (DJ) \#3 and \#13 on cell viability in human umbilical vascular endothelial cells (HUVECs).

Cells $\left(1 \times 10^{6}\right)$ in 96-well plates were incubated with and without indicated various concentrations $(10,20,50,100 \mu \mathrm{g} / \mathrm{mL}$ ) of DJ\#3 (white) and DJ\#13 (black) extracts for $24 \mathrm{hr}$. Cell viability was estimated by the MTT assay. Values are expressed as the mean $\pm \mathrm{SD}(\mathrm{n}=3)$. ${ }^{*} \mathrm{p}<0.05$, versus a media alone-treated group.

TNF-a에 의한 혈관내피세포에서 DJ\#3과 DJ\#13 추출물 의 $\mathrm{NO}$ (산화질소 nitric oxide) 생성에 미치는 영향

$\mathrm{NO}$ 는 NO 합성효소에 의해 L-arginine으로부터 생성되 는 무기 유리체로 면역반응, 세포독성, 신경전달계 및 혈관 이완 등 여러 생물학적인 과정에 관여하며 농도에 따라 세포 기능유지에 중요한 작용하기도 하고 세포독성을 일으 키기도 한다(32). TNF-a(20 ng/mL)로 산화적 스트레스를 유발시킨 혈관내피세포에서 된장 추출물의 산화질소(NO) 생성에 미치는 영향을 알아보았다. 실험결과 control군에 비하여 TNF- $a$ 를 처리한 군에서 NO생성이 현저히 감소하 였음을 확인하였고, DJ\#3과 DJ\#13(20,50, $100 \mu \mathrm{g} / \mathrm{mL})$ 을 처리했을 때 $\mathrm{NO}$ 의 생성이 TNF-a 처리군에 비해 증가하는 경향을 확인하였다(Fig. 2). 내피세포에서 소량 생성된 NO 는 혈관확장과 혈소판의 응집을 방해하여 혈류의 흐름을 원활하게 하는데, 된장추출물을 처리했을 때 증가한 $\mathrm{NO}$ 도 인체를 순환기 질환으로부터 보호해 줄 것으로 기대된다.
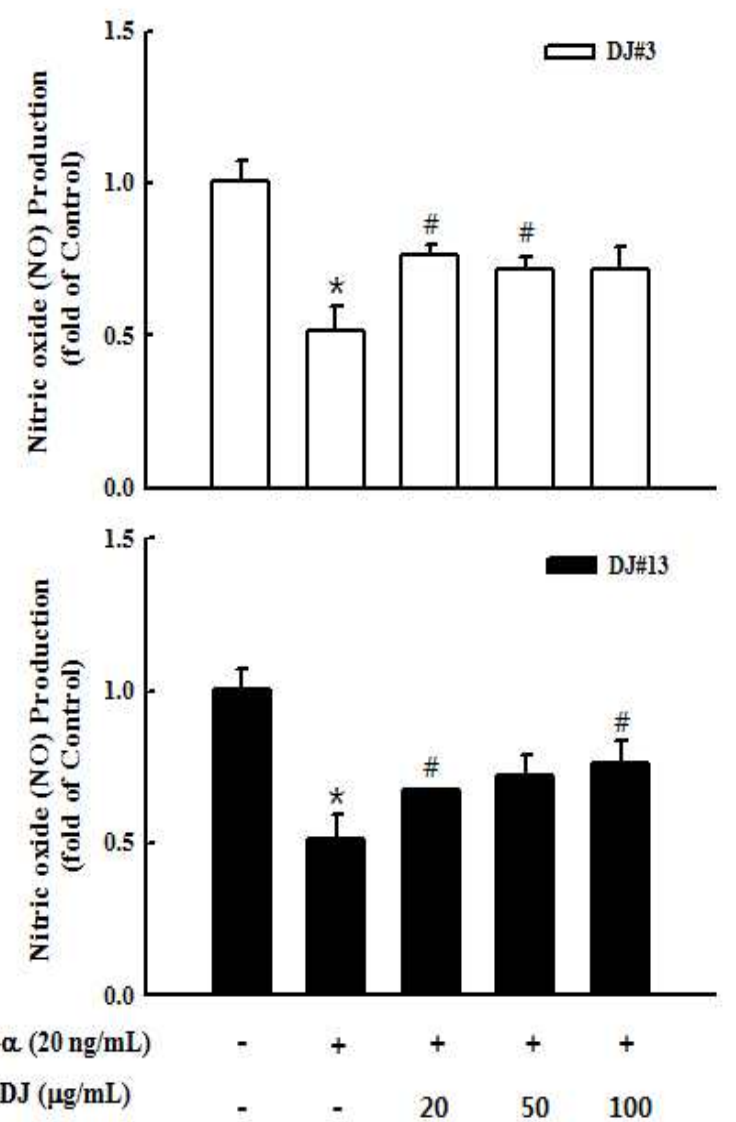

Fig. 2. Effect of DJ\#3 and DJ\#13 extracts on tumor necrosis factor (TNF)- $a$-induced NO production in human umbilical vascular endothelial cells (HUVECs).

Cells were plated in 24-well plates at $1 \times 10^{6}$ cells/well. After $48 \mathrm{hr}$, cells were treated with various concentrations $(20,50,100 \mu \mathrm{g} / \mathrm{mL}$ ) of DJ\#3 (white) and DJ\#13 (black) in the absence or presence of $20 \mathrm{ng} / \mathrm{mL}$ TNF- $a$. The media were conditioned and collected at $18 \mathrm{hr}$ after DJ\#3 and DJ\#13 treatment. NO in the conditioned media were measured using the NO Griess reagent system. Values are expressed as the mean \pm SD $(\mathrm{n}=3) .{ }^{*} \mathrm{p}<0.05$, versus a media alone-treated group.

TNF-a에 의한 혈관내피세포에서 DJ\#3과 DJ\#13 추출물 의 세포부착분자(CAMs) 발현 억제에 미치는 영향

$\mathrm{DJ} \#$ 3과 DJ\#13 추출물의 항염증 효과를 확인하기 위해 동맥경화의 초기현상을 나타내는 세포부착분자(CAMs) 생 성에 미치는 영향을 알아보고자 TNF- $a$ 로 자극한 혈관내피 세포에서 $\mathrm{DJ} \# 3$ 과 $\mathrm{DJ} \# 13$ 추출물을 농도별로 18 시간 처리한 후 ICAM-1과 VCAM-1의 발현을 ELISA를 측정하였다. 그 결과, Control군에 비하여 TNF-a $20 \mathrm{ng} / \mathrm{mL}$ 농도로 자극한 혈관내피세포의 CAMs 생성량이 증가함을 확인하였고, TNF-a 자극으로 증가된 VCAM-1의 생성량은 DJ\#3과 $\mathrm{DJ \# 13}$ 추출물을 처리했을 때 유의성 있게 감소하였고, TNF-a 자극으로 증가된 ICAM-1의 생성량은 DJ\#3 추출물 을 $100 \mu \mathrm{g} / \mathrm{mL}$ 농도로 처리했을 때 유의성 있는 감소를 보였 다(Fig. 3). 이것으로 보아, DJ\#3 추출물은 동맥경화를 유발 시키는 인자인 VCAM-1과 ICAM-1의 생성을 효과적으로 감소시켜 동맥경화를 예방할 수 있는 것으로 사료된다. 
(A)

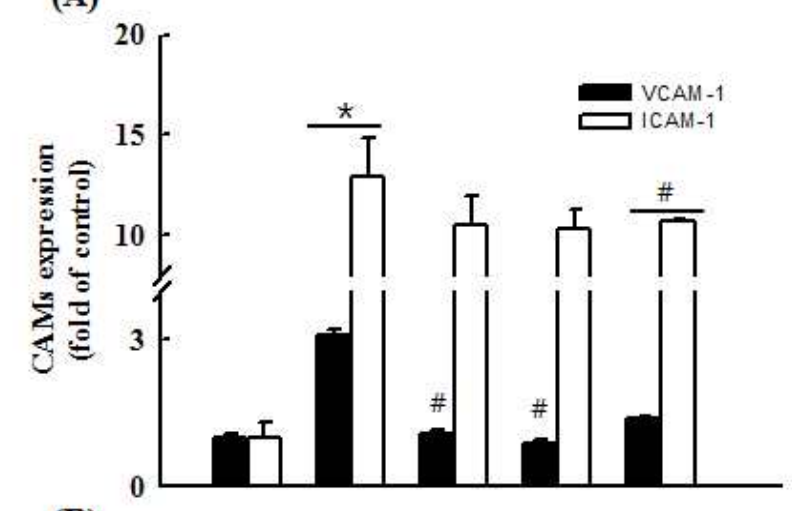

(B)

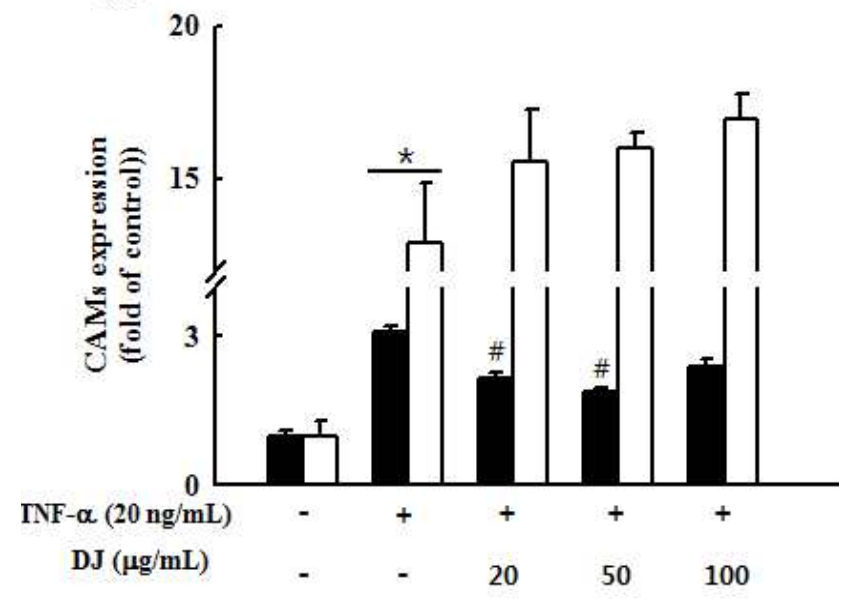

Fig. 3. Effect of DJ\#3 and DJ\#13 extracts on tumor necrosis factor (TNF)-a-induced CAMs production in human umbilical vascular endothelial cells (HUVECs).

HUVEC cells were plated in 24-well plates at $1 \times 10^{6}$ cells/well. After $48 \mathrm{hr}$, cells were treated with various concentrations $(20,50,100 \mu \mathrm{g} / \mathrm{mL})$ of DJ\#3 (A) and DJ\#13 (B) in the absence or presence of $20 \mathrm{ng} / \mathrm{mL}$ TNF- $\mathrm{a}$. The media were conditioned and collected at $18 \mathrm{hr}$ after DJ\#3 and DJ\#13 treatment. VCAM-1 and ICAM-1 in the conditioned media were measured using the VCAM-1, ICAM-1 Human ELISA kit. Values are expressed as the mean \pm SD $(n=3)$. ${ }^{*} \mathrm{p}<0.05$ VS. control, \#p<0.05 VS. TNF- $a$.

$\mathrm{TNF}-\mathrm{a}$ 에 의한 혈관내피세포에서 DJ\#3 추출물의 eNOS (endothelial nitric oxide synthase) 발현에 미치는 영향

$\mathrm{TNF}-\mathrm{a}$ 로 자극한 혈관내피세포에서 DJ\#3 추출물이 혈관 이완과 혈소판응집, 심혈관 항상성의 메카니즘 조절과 관 련 있는 NO생성효소인 eNOS의 mRNA gene 발현을 RT-PCR을 통해 확인하였다. 그 결과, 혈관내피세포만 배양 한 control군에 비하여 TNF-a $20 \mathrm{ng} / \mathrm{mL}$ 농도로 자극한 혈관 내피세포는 $\mathrm{eNOS}$ 발현이 감소하였으며, DJ\#3 추출물 처리 했을 때 농도 의존적이진 않았지만, 모든 농도에서 TNF-a 처리한 군과 비교해 eNOS 발현이 증가하였다(Fig. 4). 증가 된 $\mathrm{eNOS}$ 에 의해 생성된 $\mathrm{NO}$ 는 관상동맥을 포함하는 모든 종류의 혈관을 확장시키며 혈소판의 응고나 백혈구의 부 착, 평활근의 증식, 동맥경화를 막는 효과를 가진다(33). 위 결과로 DJ\#3 추출물에 의한 $\mathrm{eNOS}$ 생성은 혈관확장에 기여하며 혈압을 낮추는 효과가 있음을 보여주는 것으로 사료된다.
TNF-a에 의한 혈관내피세포에서 DJ\#3 추출물의 iNOS(inducible nitric oxide synthase)와COX-2(cyclooxygenase-2) 발현 억제에 미치는 영향

활성산소의 일종으로 염증유발에 중요한 역할을 하는 것으로 알려진 NO는 높은 반응성을 가진 생체 생성분자로 서, NOS(nitric oxide synthase)에 의해 L-arginine으로 생성 되는데 특히 iNOS(inducible NOS)가 염증반응에 관여한다 (34). iNOS는 세포내 존재하지 않으나 일단 자극에 의해 유도가 되면 $\mathrm{NO}$ 를 생성하며 생성된 $\mathrm{NO}$ 는 혈관확장, 세포 독성, 조직손상과 같은 작용을 하며 염증을 심화시키는 것 으로 알려져 있다(35). COX-2는 cytokine, 자외선, 세균성 내독소 및 $\mathrm{TNF}$ 등과 같은 여러 종류의 pro-inflammatory agent에 의하여 과발현되어 염증뿐만 아니라 각종 퇴행성 질환의 발병과 진행에 중요한 역할을 하는 것으로 알려져 있다(36). TNF- $a$ 에 의해 자극된 혈관내피세포부터 DJ\#3 추출물의 $\mathrm{iNOS}, \mathrm{COX}-2 \mathrm{mRNA}$ 발현에 대한 억제효과를 조사하기 위하여 RT-PCR을 수행하였다. 그 결과, 혈관내피 세포만 배양한 control군에 비하여 TNF-a $20 \mathrm{ng} / \mathrm{mL}$ 의 농도 로 처리한 경우 $\mathrm{iNOS}$ 와 $\mathrm{COX}-2$ 의 발현이 현저히 증가하였 다. DJ\#3 추출물을 처리했을 때, TNF-a 자극으로 증가된 iNOS의 발현은 $50,100 \mu \mathrm{g} / \mathrm{mL}$ 의 농도로 처리한 경우 유의 성 있게 감소하였고, 증가된 $\mathrm{COX}-2$ 의 발현은 $\mathrm{TNF}-\mathrm{a}$ 를 처 리한 군에 비하여 발현이 억제되었다(Fig. 4). Yoon 등(37) 은 큰비쑥(Artemisia fukudo) 추출물이 iNOS, COX-2 단백질 발현을 효과적으로 저해하여 항염증 효과가 있다고 보고하 였으며, 이는 DJ\#3 추출물의 염증 억제 기전과 유사한 경향 을 나타내었다.

세포부착분자(CAMs) mRNA gene 발현 억제 효과

CAMs ELISA 결과를 바탕으로 TNF-a로 자극한 혈관내 피세포에서 DJ\#3 추출물이 세포부착분자(VCAM-1과 ICAM-1)의 mRNA 유전자 발현 억제 효과를 확인하기 위해 $\mathrm{RT}-\mathrm{PCR}$ 을 측정하였다. 그 결과, TNF- $\mathrm{a}$ 처리에 의해 증가된 VCAM-1과 ICAM-1의 mRNA 유전자 발현이 DJ\#3 추출물 에 의해 감소함을 보였다(Fig. 5).

\section{세포부착분자(CAMs) 단백질 발현 억제 효과}

Western blot을 측정하여, TNF- $a$ 로 자극한 혈관내피세포 에서 DJ\#3 추출물이 세포부착분자(VCAM-1과 ICAM-1)의 단백질 발현 억제효과를 조사하였다. 그 결과, control군이 비하여 TNF- $a$ 에 의해 VCAM-1과 ICAM-1 단백질 발현이 유의하게 증가하였으나, DJ\#3 추출물을 처리했을 때 유의 한 차이는 없었지만 ICAM-1 발현은 농도 의존적으로 감소 함을 보였고, VCAM-1 발현은 $50,100 \mu \mathrm{g} / \mathrm{mL}$ 의 농도로 처리 한 경우에 $\mathrm{TNF}-a$ 를 처리군에 비하여 유의성 있게 억제효과 를 보였다(Fig. 6). 동맥경화증에서 VCAM-1 및 ICAM-1의 발현 증가와 이에 따른 세포 간 접착의 유발로 혈관협착 


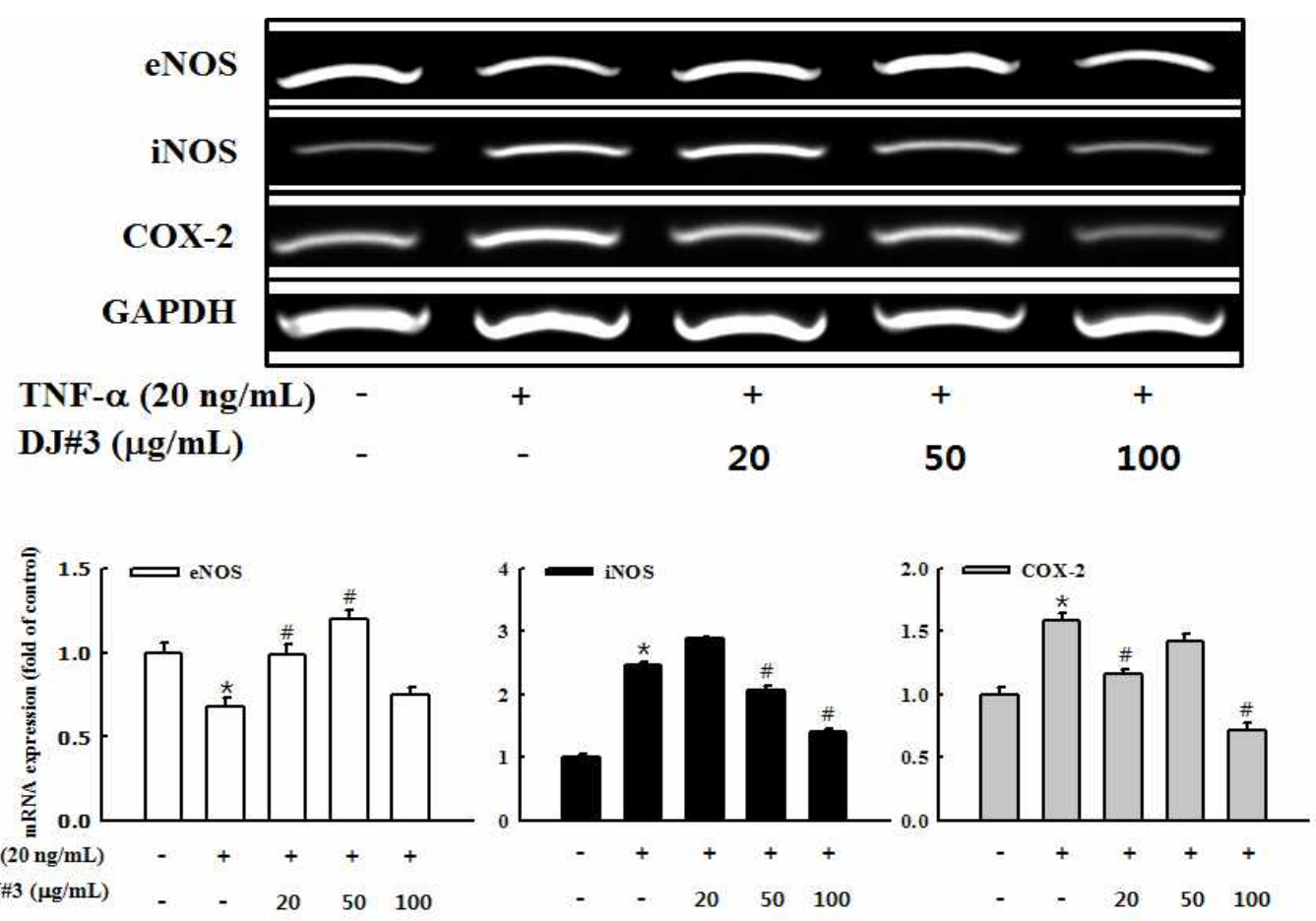

Fig. 4. Effects of DJ\#3 on eNOS, iNOS and COX-2 mRNA gene expression in tumor necrosis factor (TNF)-a-stimulated human umbilical vascular endothelial cells (HUVECs).

Cells $\left(3 \times 10^{5}\right.$ cells $)$ in $100 \mathrm{~mm}$ dishes were preincubated with and without the indicated concentrations $(20,50,100 \mu \mathrm{g} / \mathrm{mL})$ of DJ\#3 for $4 \mathrm{hr}$ and then incubated with TNF- $a$ $(20 \mathrm{ng} / \mathrm{mL})$ for $18 \mathrm{hr}$. Untreated represents the negative control without TNF-a treatment. Levels of mRNA expression were determined by RT-PCR analysis. GAPDH was used as an internal control. The data are expressed as fold basal value and are the mean $\pm \mathrm{SD}(\mathrm{n}=3)$. ${ }^{*} \mathrm{p}<0.05$ VS. control, \#p $<0.05$ VS. TNF- $a$.
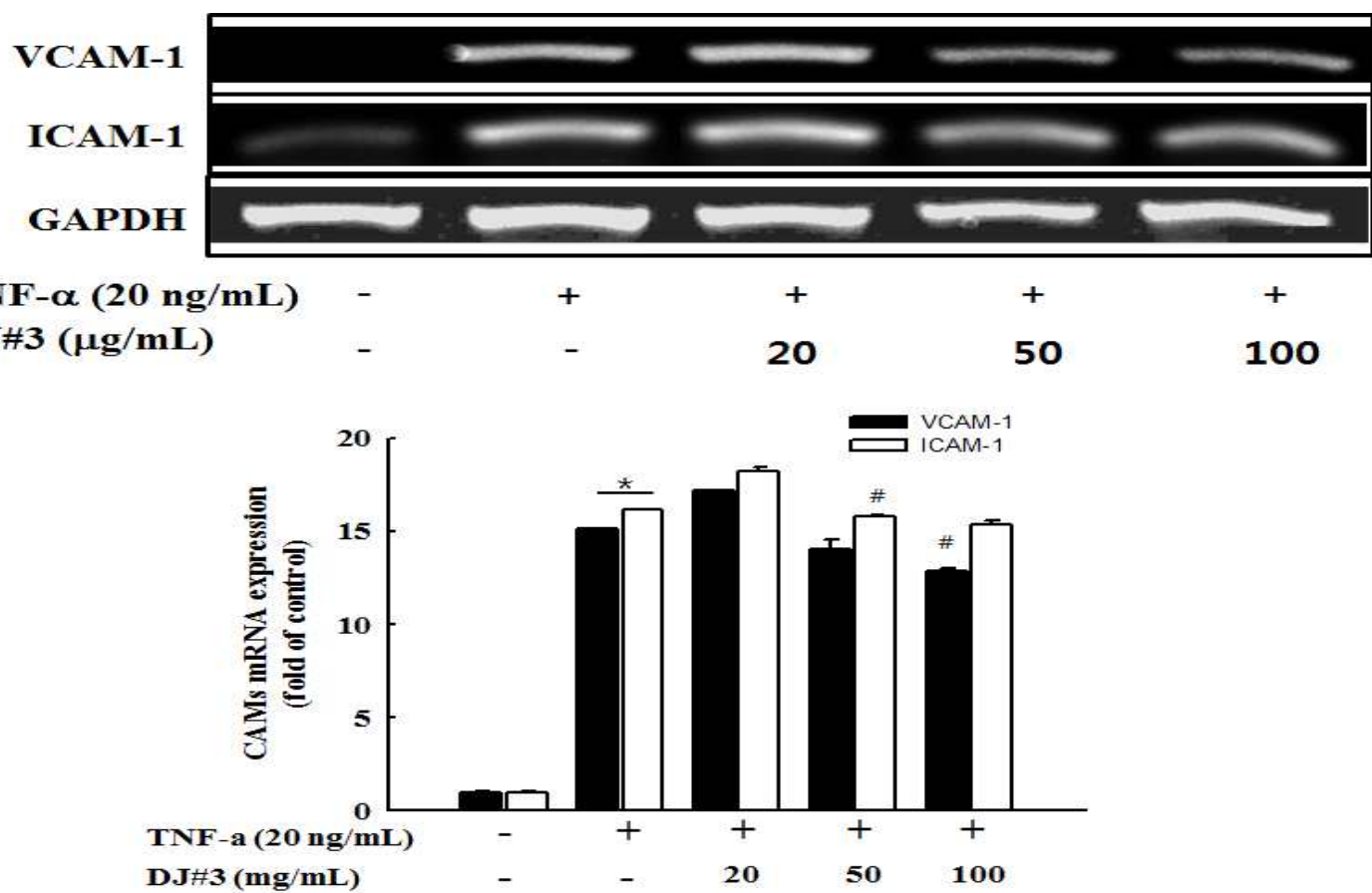

Fig. 5. Effects of DJ\#3 on VCAM-1 and ICAM-1 mRNA gene expression in tumor necrosis factor (TNF)-a-stimulated human umbilical vascular endothelial cells (HUVECs).

Cells $\left(3 \times 10^{5}\right.$ cells $)$ in $100 \mathrm{~mm}$ dishes were preincubated with and without the indicated concentrations $(20,50,100 \mu \mathrm{g} / \mathrm{mL})$ of DJ\#3 for $4 \mathrm{hr}$ and then incubated with TNF- $\mathrm{a}$ $(20 \mathrm{ng} / \mathrm{mL})$ for $18 \mathrm{hr}$. Untreated represents the negative control without TNF-a treatment. Levels of mRNA gene expression were determined by RT-PCR analysis. GAPDH was used as an internal control. The data are expressed as fold basal value and are the mean \pm SD $(\mathrm{n}=3)$. ${ }^{*} \mathrm{p}<0.05$ VS. control, \#p<0.05 VS. TNF- $a$. 

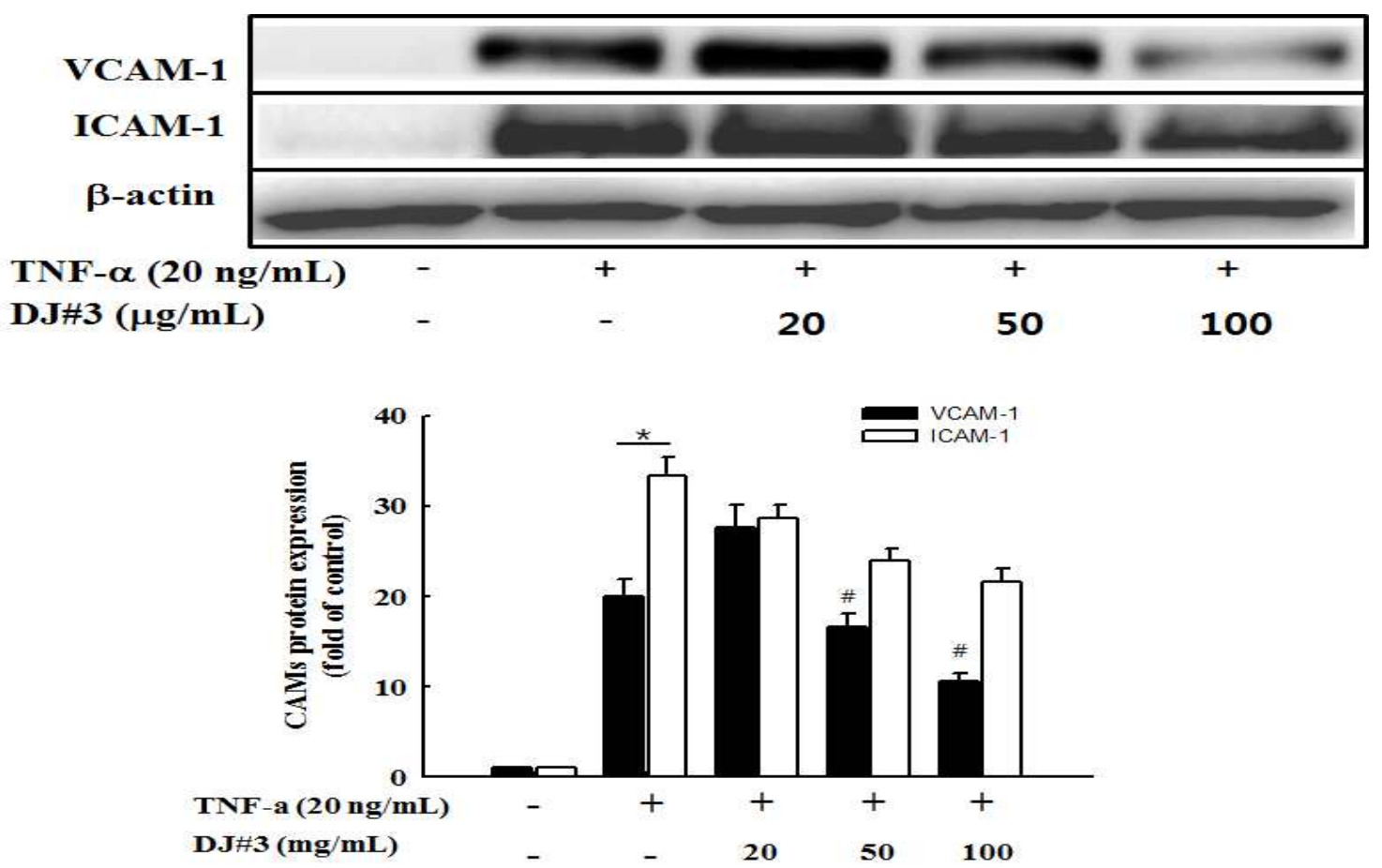

Fig. 6. Effects of DJ\#3 on VCAM-1 and ICAM-1 protein expression in tumor necrosis factor (TNF)-a-stimulated human umbilical vascular endothelial cells (HUVECs)

Cells $\left(3 \times 10^{5}\right.$ cells) in $100 \mathrm{~mm}$ dishes were preincubated with and without the indicated concentrations $(20,50,100 \mu \mathrm{g} / \mathrm{mL})$ of DJ\#3 for $4 \mathrm{hr}$ and then incubated with TNF-a $(20 \mathrm{ng} / \mathrm{mL}$ ) for $18 \mathrm{hr}$. Untreated represents the negative control without TNF-a treatment. Levels of protein expression were determined by western blot analysis. $\beta$-actin was used as an internal control. The data are expressed as fold basal value and are the mean $\pm \mathrm{SD}(\mathrm{n}=3)$. ${ }^{*} \mathrm{p}<0.05$ VS. control, \#p<0.05 VS. TNF-

및 혈전형성이 가속화된다는 사실이 국내외 많은 연구에서 입증되었고(38-40), 또한 콩의 성분인 genistein은 VCAM-1, ICAM-1의 분비를 저해함으로써 단핵구가 동맥벽으로 침 투를 저해하는 잠재성을 가진다고 보고하고 있다(41). 위의 결과로 보아 DJ\#3 추출물이 세포부착분자의 발현을 억제하 는 것으로 보아 동맥경화 초기 발생과정을 효과적으로 억제 할 수 있을 것으로 사료된다.

\section{요 약}

$\mathrm{DJ} \# 3$ 과 DJ\#13은 항염증질환 소재로서 가능성을 확인하 고자 국내 전통식품 풀질인증 된장에서 장기간 숙성된장으 로 선발된 시료이다. DJ\#3과 DJ\#13 추출물의 세포독성을 살펴보기 위하여 혈관내피세포를 이용하여 세포의 생존율 을 살펴본 결과 DJ\#3과 DJ\#13 추출물 모두 $100 \mu \mathrm{g} / \mathrm{mL}$ 의 농도까지 전혀 독성을 나타내지 않았다. 또한 $\mathrm{DJ} 33$ 과 $\mathrm{DJ \# 13}$ 추출물의 항염증 효과를 TNF- $a$ 에 의해 활성화된 혈관내피세포에서의 NO 생성, 염증관련 단백질 발현과 mRNA 유전자 발현의 변화를 통하여 확인하였다. 혈관내 피세포에 TNF- $a$ 를 처리한 결과 NO의 함량이 유의적으로 감소하였다가 DJ\#3과 DJ\#13 추출물 $(20,50,100 \mu \mathrm{g} / \mathrm{mL})$ 을 처리하였을 때 유의성은 없으나 증가하였다. 세포배양액내
VCAM-1, ICAM-1 발현을 확인한 결과 혈관내피세포에 TNF- $\alpha$ 를 처리한 군에서 증가된 VCAM-1 발현이 DJ\#3 추출 물 $20,50 \mu \mathrm{g} / \mathrm{mL}$ 에서 유의성 있는 감소를 보였다. 또한 DJ\#3 추출물은 NO 생성과 연관 있는 eNOS mRNA의 발현을 농도 의존적으로 증가하였으며, iNOS mRNA의 발현은 농 도 의존적으로 감소하였으며 이는 NO 생성 증가가 $\mathrm{iNOS}$ 의 발현억제를 경유한 것으로 사료된다. 또한 다수의 항염증 약물들의 작용기전이 되는 $\mathrm{COX}-2$ 의 생성억제를 살펴본 결과 DJ\#3 추출물은 TNF- $a$ 에 의해 발현되는 COX-2 단백질 의 발현을 억제하였음을 확인할 수 있었다. 또한, DJ\#3 추출 물은 CAMs 단백질 및 $\mathrm{mRNA}$ 발현율의 감소됨을 보였다, 이상의 결과로 보아, $\mathrm{DJ} \# 3$ 추출물은 혈관내피세포에서 TNF- $a$ 로 유도된 혈관염증을 감소하는 효과를 가지고 있으 며, 항염증물질의 연구에 기초 자료로 활용이 가능할 것으 로 기대된다. 또한 염증과 관련된 cytokine 및 단백질 발현 메커니즘에 대한 추가적인 연구가 필요할 것으로 판단된다.

\section{감사의 글}

본 연구는 농촌진흥청 국립농업과학원 농업과학기술 연 구사업(과제번호:01084501)의 지원에 의해 이루어진 것이 며 이에 감사드립니다. 


\section{References}

1. Lim SY, Rhee SH, Park KY (2004) Inhibitory effect of methanol extract of Doenjang on growth and DNA synthesis of human cancer cells. J Korean Soc Food Sci Nutr, 33, 936-940

2. Lim SY, Kim KH, Park KY, Lee SH (2007) Effect of solvent fractions from Doenjang on antimutagenicity, growth of tumor cells and production of interleukin-2. J Life Sci, 17, 791-797

3. Kim MJ, Rhee HS (1990) Studies on the changes of taste compounds during soy paste fermentation. Korean J Food Cook Sci, 6, 1-8

4. Coward L, Barnes NC, Setchell KDR, Barnes S (1993) Genistein, daidzein, and their $\beta$-glycoside conjugates: antitumor isoflavones in soybean foods from American and Asian diets. J Agric Food Chem, 41, 1961-1967

5. Hamalainen M, Nieminen R, Vuorela $\mathrm{P}$, Heinonen $\mathrm{M}$, Moilanen E (2007) Anti-inflammatory effects of flavonoids: genistein, kaempferol, quercetin, and daidzein inhibit STAT-1 and NF- $\mathrm{kB}$ activations, whereas flavone, isorhamnetin, naringenin, and pelargonidin inhibit only $N F-\kappa B$ activation along with their inhibitory effect on iNOS expression and NO production in activated macrophages. Mediators Inflamm, 2007, 45673

6. Ungar Y, Osundahunsi OF, Shimoni E (2003) Thermal stability of genistein and daidzein and its effect on their antioxidant activity. J Agric Food Chem, 51, 4394-4399

7. Guo JM, Xiao BX, Liu DH, Grant M, Zhang S, Lai YF, Guo YB, Liu Q (2004) Biphasic effect of daidzein on cell growth of human colon cancer cells. Food Chem Toxicol, 42, 1641-1646

8. Park KY, Moon SH, Baik HS, Cheigh HS (1990) Antimutagenic effect of Doejang (Korean fermented soy paste) toward aflatoxin. J Korean Soc Food Sci Nutr, 19, 158-162

9. Cui CB, Lee EY, Lee DS, Ham SS (2002) Antimutageniic and anticancer effects of ethanol extract from Korean traditional Doenjang added sea tangle. J Korean Soc Food Sci Nutr, 31, 322-328

10. Kim SH (1998) New trends of studying on potential activities of Doenjang-fibrinolytic activity. Korea Soybean Digest, 15, 8-15

11. Lee BK, Jang YS, Yi YS, Chung KS, Choi SY (1997) Immunomodulators extracted from Korean-style fermented soybean paste and their function. Isolation of B cell mitogen from Korean-style fermented soybean paste.
Korean J Immonol, 19, 559-569

12. Suh HJ, Suh DB, Chung SH, Whang JH, Sung HJ, Yang HC (1994) Purification of ACE inhibitor from soybean paste. Appl Biol Chem, 37, 441-446

13. Hwang JH (1997) Angiotensin I converting enzyme inhibitory effect of Doenjang fermented by $B$. subtilis SCB-3 isolated from Meju, Korean traditional food. J Koeran Soc Food Sci Nutr, 26, 775-783

14. Yang BK, Jeong SC, Hur NJ, Ha SO, Kim KY, Kym KH, Yun JW, Song CH (2000) Hypoglycemic effect of extracts of soybean paste containing mycelia of mushrooms in streptozotocin-induced diabetic rats. Korean J Mycol, 28, 126-129

15. Choe GS, Lim SY, Choi JS (1998) Antioxidant and nitrite scavenging effect of soybean, Meju and Doenjang. Korean J Life Sci, 8, 473-478

16. Kim MH, Im SS, Kim SH, Kim GE, Lee JH (1994) Antioxidative materials in domestic Meju and Doenjang 2. Separation of lipophilic brown pigment and their antioxidative activity. J Korean Soc Food Nutr, 23, 251-260

17. Choi UK, Ji WD, Chung HC, Choi DH, Chung YG (1997) Optimum condition for pigment production and antioxidative activity of the products by Bacillus subtilis DC-2 with response surface methodology. J Korean Soc Food Sci Nutr, 26, 620-624

18. Ross R (1995) Cell biology of atherosclerosis. Annu Rev Physiol, 57, 791-804

19. Lee ES, Ju HK, Moon TC, Lee EK, Jahng YD, Lee SH, Son JK, Baek SH, Chang HW (2004) Inhibition of nitric oxide and tumor necrosis factor-a (TNF-a) production by propenone compound through blockade of nuclear factor (NF)- $\kappa \mathrm{B}$ activation in cultured murine macrophages. Biol Pharm Bull, 27, 617-620

20. Lee TH, Kwak HB, Kim HH, Lee ZH, Chung DK, Baek NI, Kim JY (2007) Methanol extracts of Stewartia koreana inhibit cyclooxygenase-2 (COX-2) and inducible nitric oxide synthase (iNOS) gene expression by blocking NF- $k \mathrm{~B}$ transactivation in LPS-activated RAW 264.7 cells. Mol Cells, 23, 398-404

21. Nathan C (1992) Nitric oxide as a secretory product of mammalian cells. FASEB J, 6, 3051-3064

22. Mohamed AK, Bierhaus A, Schiekofer S, Tritschler H, Ziegler R, Nawroth PP (1999) The role of oxidative stress and NF- $\kappa \mathrm{B}$ activation in late diabetic complications. Biofactors, 10, 157-167

23. Chen JW, Chen YH, Lin FY, Chen YL, Lin SJ (2003) 
Ginkgo biloba extract inhibits tumor necrosis factor-a -induced reactive oxygen species generation, transcription factor activation, and cell adhesion molecule expression in human aortic endothelial cells. Arterioscler Thromb Vasc Biol, 23, 1559-1566

24. Kanters E, Pasparakis M, Gijbels MJ, Vergouwe MN, Partouns-Hendriks I, Fijneman RJ, Clausen BE, Forster I, Kockx MM, Rajewsky K, Kraal G, Hofker MH, de Winther MP (2003) Inhibition of NF- $\kappa$ B activation in macrophages increases atherosclerosis in LDL receptor-deficient mice. J Clin Invest, 112, 1176-1185

25. Kunsch C, Luchoomun J, Grey JY, Olliff LK, Saint LB, Arrendale RF, Wasserman MA, Saxena U, Medford RM (2004) Selective inhibition of endothelial and monocyte redox-sensitive genes by AGI-1067: a novel antioxidant and anti-inflammatory agent. J Pharmacol Exp Ther, 308, 820-829

26. Huh JI, Jin SY (2011) A survey on the perception of agricultural food accreditation and traditional food quality certification. J Korean Soc Food Cult, 26, 220-229

27. National Agricultural Products Quality Management Service (2012) Traditional Food Standards. Anyang, Korea, p 88-93, p 99-100

28. Kang JE, Choi HS, Choi HS, Park SY, Song J, Choi JH, Yeo SH, Jung ST (2013) The quality characteristics of commercial Deonjang certified for traditional foods. Korean J Community Living Sci, 24, 537-542

29. Je JY, Park PJ, Kim EK, Ahn CB (2009) Antioxidant and angiotensin I converting enzyme inhibitory activity of Bambusae caulis in liquamen. Food Chem, 113, 932-935

30. Lee SJ, Kim EK, Kim YS, Hwang JW, Lee KH, Choi DK, Kang H, Moon SH, Jeon BT, Park PJ (2012) Purification and characterization of a nitric oxide inhibitory peptide from Ruditapes philippinarum. Food Chem Toxicol, 50, 1660-1666

31. Bradford MM (1976) A rapid and sensitive method for the quantitation of microgram quantities of protein utilizing the principle of protein-dye binding. Anal Biochem,
$72,248-254$

32. Kim JY, Jung KS, Jeong HG (2004) Suppressive effects of the kahweol and cafestol on cyclooxygenase-2 expression in macrophages. FEBS Lett, 569, 321-326

33. Li H, Forstermann U (2000) Nitric oxide in the pathogenesis of vascular disease. J Pathol, 190, 244-254

34. Sarkar D, Fisher PB (2006) Molecular mechanisms of aging-associated inflammation. Cancer Lett, 236, 13-23

35. Vodovotz Y, Russell D, Xie QW, Bogdan C, Nathan C (1995) Vesicle membrane association of nitric oxide synthase in primary mouse macrophage. J Immunol, 154, 2914-2925

36. Sung MS, Kim YH, Choi YM, Ham HM, Jeong HS, Lee JS (2011) Anti-inflammatory effect of Erigeron annuus L. flower extract through heme oxygenase-1 induction in RAW 264.7 macrophages. J Korean Soc Food Sci Nutr, 40, 1507-1511

37. Yoon WJ, Lee JA, Kim KN, Kim JY, Park SY (2007) In vitro anti-inflammatory activity of the Artemisia fukudo extracts in murine macrophage RAW 264.7 cells. Korean J Food Sci Technol, 39, 464-469

38. Hwang SJ, Ballantyne CM, Sharrett AR, Smith LC, Davis CE, Gotto AM Jr, Boerwinkle E (1997) Circulating adhesion molecules VCAM-1, ICAM-1, and E-selectin in carotid atherosclerosis and incident coronary heart disease cases. Circulation, 96, 4219-4225

39. Li H, Cybulsky MI, Gimbrone MA Jr, Libby P (1993) An atherogenic diet rapidly induces VCAM-1, a cytokine-regulatable mononuclear leukocyte adhesion molecule, in rabbit aortic endothelium. Arterioscler Thromb, 13, 197-204

40. Schmidt A, Goepfert C, Feitsma K, Buddecke E (2002) Lovastatin-stimulated superinduction of E-selectin, ICAM-1 and VCAM-1 in TNF- $a$ activated human vascular endothelial cells. Atherosclerosis, 164, 57-64

41. Rimbach G, Valacchi G, Canali R, Virgili F (2000) Macrophages stimulated with IFN- $\gamma$ activate NF- $\kappa \mathrm{B}$ and induce $\mathrm{MCP}-1$ gene expression in primary human endothelial cells. Mol Cell Biol Res Commun, 3, 238-242 